\title{
UNA FÁBULA SOBRE LA INMIGRAGIÓN A AMÉRIGA: FIEVEL Y EL NUEVO MUNDO (1986)
}

\author{
Igor Barrenetxea Marañón
}

Universidad del País Vasco

"siempre ha parecido clara la importancia de la emigración en la formación del carácter del pueblo americano"

(Hernández Alonso, 1996: 431)

\section{INTRODUCCIÓN}

Las andanzas de un ratón llamado Fievel estaban destinadas a un público infantil que podía divertirse, entristecerse o bien alegrarse ante un personaje de ficción diminuto, cariñoso y valiente. Sin embargo, debemos ir más allá de esta presentación para apreciar el valor de la imagen. Fievel y el Nuevo Mundo fue el comienzo de una saga de películas ${ }^{1}$ protagonizadas por este ratón y su familia procedente de la Rusia zarista, en donde son perseguidos por los gatos hasta que deciden emigrar a América: la tierra prometida (Degler, 1986: 49). La imagen no es inocente, apunta con criterio Marc Ferro. Es un espejo que en ocasiones no sólo habla del pasado sino de la sociedad en donde germina. Ferro considera, así, que el cine es "un agente de la historia" (1995: 21). Ayuda, entre otras cosas, a "la formación de las identidades y el imaginario colectivo" (De Pablo, 2001: 17).

En este caso, Fievel es un filme construido con varios elementos de sumo interés para los historiadores. Producido por Steven Spielberg y protagonizado por una familia de ratones judíos que huye de las persecuciones en la vieja Europa, narra la historia velada de un pueblo errante con destino a otra tierra prometida. En este caso no es Palestina sino Estados Unidos. Y elabora, así mismo, un retrato genérico de la lucha de los inmigrantes de distintas nacionalidades llegados a América, en su aspiración por alcanzar la libertad. Sin duda, esto explicaría por qué Estados Unidos se define como "una mezcla de pueblos europeos, una nación de inmigrantes, procedentes de distintas partes del mundo" (Hernández Alonso, 1996: 431). Los elementos de la ficción, de todas maneras, no tienen una sujeción histórica directa sino que la muestran subrepticiamente, lo que Rosenstone denomina metáfora fílmica (1997: 58). Por

1 Entre las que caben señalar: Fievel va al oeste, Fievel en Manhattan y Fievel y el misterio del monstruo. 
tanto, Fievel es un viaje de iniciación de miles de judíos y europeos padeciendo progroms u otra clase de persecuciones, o sólo buscando un lugar mejor donde vivir. Tal como señala Degler, "Estados Unidos se convirtió en la frontera de Europa" (1986: 50).

\section{ANÁLISIS DE SUS ELEMENTOS}

\section{a) La familia de Fievel en Rusia}

El inicio del filme se ambienta en un nevado invierno ruso, en la localidad de Shostka, durante 1885, una época dura en la que se desarrollaron diversos progroms contra los judíos. El marco histórico sólo es un referente contextual, que establece los marcos del discurso cinematográfico. Al lado de una casa habitada por un familia humana, se sitúa la de los Mousekewitz. Este paralelismo se vislumbrará en otros momentos, cuando se embarcan rumbo a América y cuando son recibidos allí, lo cual evidencia una alegoría entre los ratones, protagonistas del filme, y lo que representan. Al calor de la lumbre se halla recogida la familia de Fievel, sonriente a pesar de las condiciones climáticas tan adversas en el exterior (viento helado y nieve). Todos ríen y se divierten. Pero cuando la madre quiere que se acuesten, el padre, con un tono suave le espeta: "Pero, mamá, es Janucá". La festividad del Janucá, o fiesta de las luminarias, es una tradición judía y dura ocho días. No parece casual que se aluda a ella, ya que encarna la independencia judía cuando los helenos quisieron hacerles renunciar a sus creencias en el siglo II a.C. La representación de la victoria, en la que se utiliza el candelabro de siete brazos (aunque en el filme no aparezca), representa esa identidad hebrea. La madre replica al padre: "Para ti siempre es Janucá". Lo cual puede tener una doble lectura: la festividad como un momento familiar único y reivindicativa de esta identidad religiosa. El padre de Fievel es representado como un ratón afable y bonachón que toca el violín, acompañado por Tania, la hermana de Fievel. Se trata de una escena iluminada por el fuego donde se aprecia la pobreza y la humildad, pero donde prevalece el candor familiar. Fievel va vestido con una ropa que le queda holgada y se aprecia un claro remendón en ella. Con suma ilusión, el padre les ofrece los regalos propios de la festividad, entrega a Tania una babuska (pañuelo) y a Fievel una "gorra nueva" que ha estado en su familia "por tres generaciones". La gorra que regala a Fievel, aunque le queda grande, encarna la tradición, el legado familiar que es significativo en el marco de esta cultura y que preservarán, incluso, una vez lleguen a América. El toque de humor campechano lo pone Fievel cuando ve que el gorro se le desliza tapándole los ojos.

La relación con el pasado no deja de ser importante. Se percibe cuando el padre se sienta a contarles la leyenda del ratón de Minks: "era tan grande como un árbol y su cola medía más de cien metros". El padre conforma con su mano una sombra que se refleja en la pared. Y añade: "era tan grande que asustaba a todos los gatos". Pero la madre se le acerca y le reprende diciendo que hable de otra cosa, ante el pavor que produce la mención de la palabra gato. A lo que Fievel, ilusionado, para cambiar de tema le pide que hable "ide América!". Mientras, la madre responde con cierto cinismo: "otro cuento de hadas". Al padre se le ilumina el rostro y exclama: "América, iqué lugar!". Sus hijos, Tania y Fievel, le secundan y repiten con su coro de voces infantiles. El padre puntualiza que allí hay agujeros de ratón en cada pared y migajas de pan por todas partes y que "puedes decir lo que quieras". Y lo más importante: "En América, no hay gatos". No es casual que se esgrima como una de las virtudes más relevantes para describir América su derecho a decir lo que se quiera. Puesto 
que, como señala Ferro, "todas las sociedades acogen las imágenes en función de su propia cultura" (1995: 25) y, en este caso, entendemos que es así. Tiene una implicación mitificadora del imaginario que aún se mantiene y es una premisa del espíritu norteamericano: la libertad de expresión (síntesis de sus libertades).

Del mismo modo, la presunta ausencia de gatos, que encarnan la amenaza mortal para los ratones, se estima como un simbolismo genérico de los prejuicios que existían en el Viejo Continente, pero que, obviamente, no desaparecen en América. Por tanto, "las generalizaciones fílmicas se logran mediante la condensación, la síntesis y la simbolización" (Rosenstone, 1997: 59). Frase a la que se podría añadir: matizadas, con una pizca de grata y paternal ficción. Puesto que, para todo inmigrante europeo, América es una tierra ideal abierta a la "libertad religiosa, democracia política, mayor igualdad social y una segunda oportunidad para los jóvenes" (VV.AA, 1980: 477), un lugar de esperanza al que dirigirse. Pero no por ello, en esa salvaguarda identitaria, comporta renunciar a la herencia cultural o religiosa de la que se parte.

La dulce representación familiar se ve interrumpida por un temblor de tierra que altera la tranquilidad y hace efectivos los miedos de la madre. El bebé ratón rompe a llorar, mientras unas hordas salvajes de hombres montados a caballo, con sus rostros oscuros y su perfil tenebroso (cosacos), lanzan teas incendiando los tejados de la pacífica población. Un torbellino de imágenes se apodera de la pantalla. De manera paralela, mientras los civiles, niños, mujeres y hombres huyen, los ratones salen despavoridos de sus hogares, intentando poner a salvo los pocos enseres que pueden llevar con ellos. Tras los asaltantes aparecen los gatos con un brillo malvado en sus ojos, lanzando espumarajos por la boca, lenguas fuera y ojos inyectados en sangre, que, con vena asesina, persiguen a los pobres ratones por la nieve. Fievel, con esa ingenuidad que le caracterizará a lo largo del filme, sale corriendo con una sartén y una cuchara, dispuesto a espantarlos metiendo ruido. Pero, claro, eso no les asusta y tiene que huir perseguido por dos de ellos dispuestos a zampárselo.

Como todo buen filme de dibujos que se precie, los gatos son incapaces de capturarle, chocan entre sí (con humor), corren por la nieve con la consabida torpeza, mientras que Fievel con suerte y agilidad endiablada, a pesar del peligro, se zafa de ellos. La escena concluye con la marcha de los gatos y Fievel, con una sonrisa traviesa y aturdida, es reconvenido por su madre para que no vuelva a hacer nada parecido. Pero la desgracia se ha cebado en ellos. La casa donde viven está ardiendo. El padre, apesadumbrado, afirma: "En América, no hay gatos". En este caso, la inmigración de la familia de Fievel se ve forzada por esta situación adversa de persecución. Cabe interpretarse como que van en busca de una mayor tolerancia $y$, como se subrayará, de una libertad en que poder vivir plenamente sin miedo a los gatos (Bosch, 2005: 248).

La familia se traslada a América en busca de una oportunidad de vivir a salvo de amenazas. Sin embargo, parte de esta emigración también se explica por una cuestión de intolerancia religiosa, de búsqueda de nuevas oportunidades. Acuden atraídos por esta "tierra de promisión" (Hernández Alonso, 1996: 434), impulsada por la publicidad oral, el boca a boca tan efectivo a la hora de mitificar la imagen de un lugar. Todo ello vino acompañado por el fuerte crecimiento democrático de las comunidades judías durante el siglo XIX. Muchos optaron por trasladarse a Francia, Inglaterra o Rusia pero, sobre todo, a América (Suárez, 2003: 528). Aunque este salto oceánico vino acelerado por una ola de progroms, iniciados en 1881, del régimen zarista contra los judíos (Johnson, 2001: 484). 
Entre 1880 y 1930, unos cuatro millones de personas procedentes de Rusia y Polonia emigraron a América. En su mayoría escogieron el medio urbano americano para emprender una nueva vida (VV.AA, 1980: 478). Hay que matizar que, aunque el protagonismo sea dado a una familia de ratones judíos, el filme también incorpora a otros grupos nacionales que buscaban en ese país un sitio donde no hubiese gatos, un elemento que conforma los prejuicios ya fueran raciales, clasistas o sociales, en una metáfora genérica que, en el fondo, radica en el mensaje que se enlaza con la mitificación que existe sobre el espíritu de libertad americano, en estas tierras dispuestas como un nuevo horizonte (Degler, 1986: 52). Los europeos (también miles de asiáticos, pero resultaron mucho peor tratados) fueron guiados a América con la idea de mejorar sus condiciones de vida (Hernández Alonso, 1996: 433). Allí se encontraron con una tierra abierta a las oportunidades, pero no exenta de contradicciones, en un mundo que no siempre les recibió con los brazos abiertos, sino con la natural desconfianza de los que ya vivían allí, los nativos y primeros inmigrantes, que no eran ajenos a la intolerancia, la xenofobia o el racismo (Degler, 1986: 61).

\section{b) La marcha al Nuevo Mundo}

Tras ver quemado su hogar, la familia de Fievel opta por emigrar. La siguiente escena nos sitúa en el puerto de Hamburgo, donde una cola de inmigrantes espera en el muelle para embarcar en un velero. Por su parte, los ratones forman su propia cola en una pasarela de los amarres del navío. Allí, una banda de música, vestida con trajes típicos germanos, despide a los ratones que marchan en fila india al compás subiendo por la cuerda. En esa pizca de humor, Fievel, agarrado a la cola de su padre, se detiene, con el fin de preguntar si lo que está viendo es el océano, frenando de improviso a los que vienen por detrás. La música se silencia. Y le instan a seguir. Claro que Fievel vuelve a hacer de las suyas. La orquesta, que marca el ritmo de la marcha por la cuerda, se enfada al verse interrumpida por segunda vez. Y, lo hará por tercera vez. Toda la fila de roedores le pide que siga caminando. Fievel, de manera ingenua, explica que sólo quería ver y su padre, con un deje de ironía, le responde que es la "última vez que le lleva a América". El ansia curiosa le caracterizará. Pero esta circunstancia nos ha permitido observar a otros ratones y lo que significa para un ratón (o inmigrante) de campo el ancho mar, el nuevo mundo que se abre ante sus ojos. Se trata de apreciar las facetas de lo que implica la fascinación del descubrimiento de nuevos elementos de la realidad y de espacios desconocidos.

En el momento de la partida, dos gaviotas se despiden del barco y una le dice a la otra: "¿Sabes? Tengo un primo en América". La otra con mucho humor le responde: "Todo el mundo tiene a alguien en América". Sin duda, no son casuales estas palabras, ya que simbolizan la corriente migratoria que guió a millones de europeos al continente americano, lo que establece ese nexo entre ambos mundos. Entre 1800 y 1930, Estados Unidos recibió cuarenta millones de europeos, ya fueran británicos, alemanes, irlandeses, italianos, españoles y judíos del Este, como es el caso de nuestros protagonistas (Degler, 1986: 51). Durante la travesía en barco se observarán ratones de distintas nacionalidades que encarnan esta ola migratoria en busca de "autonomía y libertad" (Blanco, 2000: 38). Pero el viaje no está exento de peligros. Una vez en el buque, mientras que en la cubierta superior se hallan los emigrantes humanos, bajo ella se ubican los ratones. El paralelismo no es casual sino didáctico para el público infantil al que está destinado el filme. Tania, a diferencia de Fievel, e igual que su madre, 
señala que deberían haberse quedado en Rusia. Sin embargo, el padre siempre optimista le replica que mientras "estemos juntos todo estará bien". Pero Fievel es un ratoncito audaz e impulsivo, lo cual acarrea consecuencias. Y cuando su padre le explica que el mar está lleno de peces, sin poderse contener, corre donde su madre a decírselo. Ella le responde sarcásticamente que mientras no haya visto "gatos...". El término provoca la reacción asustadiza y exagerada de otros ratones. Todos tienen el mismo miedo. "Ah, qué lindo será llegar a América donde no tendremos que preocuparnos más de los gatos porque no hay gatos en América pero, en cambio, en nuestra Rusia, ah...", exclama públicamente el padre. Se incide en esa imagen lírica fermentada y sostenida por el imaginario de que Estados Unidos era "la esperanza de los oprimidos" (Degler, 1986: 54), frente a una Europa atrasada y arcaica. Los gatos encarnan estos valores negativos que en América confían no encontrar.

El barco reúne a ratones de otras identidades caracterizadas por marcados tópicos. Pero el viaje del emigrante no es de placer, aderezado por esta unión de ir en busca de la tierra prometida, sino una odisea complicada y peligrosa. "El viaje no era en absoluto confortable" (Hernández Alonso, 1996: 435). El navío se ve atrapado por una gigantesca tormenta que pone en peligro a los ratones. El interior del barco se vuelve lúgubre y silencioso. La madre de Fievel lacónicamente afirma: "Es el fin del mundo". Mientras, el pequeño, que se ha quemado con la brasa de una estufa, se ve subido en una pastilla de jabón. El agua traicionera le lleva sin poder remediarlo, en este vaivén del barco, hasta la escalerilla que da a la cubierta superior. La puerta de acceso se abre y se cierra abatida por el viento y el agua que rompe sobre el barco. De ella procede el agua de mar que se filtra en las cubiertas y caen un par de peces. El pequeño ratón, ingenuo e inconsciente, sube a cubierta mientras los truenos y relámpagos rasgan el cielo. El padre le sigue queriendo impedírselo, pero Fievel se ve arrastrado por la tormenta en una escena angustiosa, en la que su padre no consigue salvarlo de verse arrastrado por el oleaje. El mar, convertido en un oscuro monstruo, se lanza contra el barco. Finalmente, en una de las arremetidas, Fievel sale despedido. Todo ello encarna los desafíos a los que debe enfrentarse el inmigrante. Y revela las malas condiciones de vida en los buques. La dúctil imagen no evita componer esa estampa de la dureza y las dificultades que entraña alcanzar el sueño americano.

\section{c) América: la Tierra Prometida}

Tras la tormenta, el barco atraca en Nueva York. Se muestra a los inmigrantes humanos atravesando una pasarela y un funcionario cuenta su número; por debajo, a través de otra tabla, en paralelo, los ratones siguen el mismo camino. Un funcionario ratón les toma los datos. El Castle Garden "se convirtió en el centro de recepción obligado de todo emigrante" (Hernández Alonso, 1996: 435). Y eso es lo que vemos vivir a la familia de Fievel a su llegada a América. "Sólo al 2 por 100 de los recién llegados se les negaba la entrada y eran devueltos a sus países de origen" (Bosch, 2005: 249), por diversos motivos. Cuando el funcionario de la aduana les pregunta, en el filme, cuántos son los miembros de la familia, el padre de Fievel contesta que cinco, aunque se da cuenta de que son cuatro, porque piensa que Fievel ha fallecido. Pero está vivo. Vemos una solitaria botella en un mar dorado y en calma en donde se asoma un desorientado Fievel. Sus ojos se abren como platos cuando atisba la Estatua de la Libertad. Una vez en tierra, se encuentra con un palomo francés, Henry. Fievel le confiesa que pensaba que América era más grande, al creer que es la isla donde está la Estatua. Heny 
le advierte de su error. No es casual que el palomo sea francés. La Estatua fue un regalo del pueblo francés que, en 1886, conmemoraba los cien años de la independencia de Estados Unidos. La Estatua es colosal, al medir cuarenta y siete metros de altura; erigida sobre un pedestal, siendo de cobre, y situándose en la isla de Bedloe, bien visible a la entrada del puerto de Nueva York (Johnson, 2001: 534).

Tras bañarle y secarle en su alojamiento, Henry observa el gesto compungido de Fievel y le indica: "Lo sé, mi pequeño inmigrante; tú quieres encontrar a tu familia. Y lo harás". Es referencial que donde Fievel coloca una bolsa de agua caliente haya, junto a ella, banderitas americanas (elemento de esta escenografía patriótica). Sin embargo, Fievel se halla compungido porque piensa que nunca volverá a encontrarse con su familia. Así que le replica: "Esto es América, la tierra de la esperanza". A lo que añade que "nunca di nunca, porque siempre tus sueños se harán realidad". Animado y convencido por Henry de que es posible encontrar a su familia, le guía al Castle Garden. Los elementos son elocuentes y representativos, retratan el modo en el que alcanzaban los inmigrantes Estados Unidos y cómo se procedía a inscribirlos para entrar en el país. Pero, como hemos visto, hay algo más. América es descrita por Henry como la tierra de la esperanza.

Junto al Castle Garden humano se halla el mundo de los ratones, en donde se ofrecen visitas guiadas para ver el puente de Brooklyn y diferentes productos. En ese recorrido aparece un nuevo personaje: Honorio, ese rata. Su aspecto, de marcadas ojeras negras y gesto adusto, lo perfila como un ser desagradable y malo. Se halla contando avariciosamente dinero y tiene a su servicio una cucaracha. Aunque América se presenta ante Fievel como un país de esperanzas y oportunidades, de personas optimistas que proceden de diversos países, dispuestos a sacar lo mejor de sí mismas, también están los que pretenden corromper esos ideales. Una paloma, amiga de Henry, que le ha traído desde la Estatua a la ciudad, le deja a Fievel justo en la maleta que sirve de refugio a Honorio. Fievel se introduce por un agujero y acaba a los pies de éste, a quien explica que anda en busca de su familia. Honorio, hábilmente, le responde que sabe "exactamente" donde están. Sin embargo, su intención es venderle como trabajador. "Confía en mí, chico, confía en mí", le dice cuando sabemos que no debe hacerlo. Honorio le guía hasta un lugar en el que se puede leer en inglés "help always wanted". Al abrir la puerta, Fievel cree que ahí está su familia pero, enseguida, le agarra un ratón enorme que se ríe sarcástica y cruelmente del pobre Fievel.

Fievel: Pero, ¿y mi familia?

Honorio: No necesitas familia, ya tienes trabajo.

La puerta se cierra tras la marcha de Honorio y coloca una tranca que le impide salir: "Eres mío" le espeta Bob, el otro ratón. Un numeroso grupo de ratones, explotados por éste, son urgidos a trabajar. Es la otra cara de la inmigración. En paralelo, vemos unas mujeres que cosen, lo cual incide, una vez más, en esta alegoría en la que cabe identificar ratones-inmigrantes. Esa misma noche, vemos a los ratones dormir en cestos colgados del techo, en jarrones o en el suelo. Esta escena representa la dura vida laboral y las dificultades que encuentran en su camino los recién llegados, encerrados y explotados sin ningún tipo de defensa de sus derechos al ser atrapados por esta red de trabajo clandestino (Hernández Alonso, 1996: 454). Es ese otro rostro de la injusticia humana ante la cual, desgraciadamente, el inmigrante está desvalido y es incapaz de hacerle frente si no es con nuestro apoyo o solidaridad. 
En este imaginario mágico, Fievel insiste en querer buscar a su familia y salir de allí, con lo que decide emular a la "ratona de cabello largo", que dejaría caer su cabellera para huir. Resuelve hacerlo anudando varias sábanas. Otro ratón mayor que Fievel pero joven, Toni Topón, personaje alegre y positivo, le ayuda. Fievel desciende por la cuerda y huye, sin saber hacia dónde dirigirse.

Paralelamente, su familia le echa en falta. Una familia nunca está completa si falta uno de sus miembros, otro de los valores implícitos. En el inmigrante, esa sensación de pérdida o ausencia es mayor. Su hermana tiene la intuición de que está vivo. Una fotografía de Fievel rodeada de caracteres en yiddish nos recuerda su herencia judía y ese sentimiento de nostalgia que anida en sus padres. Pero esta tradición cultural judía desaparece. Lo que desvela el proceso de acomodación de la comunidad judía que impulsó un "entendimiento con el medio americano", hasta "conseguir una síntesis de las tradiciones judías y americanas" (Adams, 1985: 206).

\section{d) Los valores americanos}

Esperanzas, sueños e ilusiones se estrellan contra la dura y tersa realidad del inmigrante que se ve arrojado de su mundo hacia otro que ha idealizado y que, sin embargo, no es tan perfecto como había creído. Aún con todo, este sueño se abre camino entre las calles de la ciudad. Tras huir Fievel de Bob y su taller de explotación clandestino, deambula por la urbe. A través de un cristal, con ojos tristes, ve como, en lo que parece una escuela, unos ratones juran la bandera americana (un elemento recurrente). Se encuentra con un mundo hostil y nada generoso, moderno, por otra parte; lejos del atraso rural de las primeras escenas en Rusia. Se pega un buen susto cuando, caminando por unas vías, un tren aparece de pronto y le pasa por encima. Cae a un montón de hollín. Escuchará el sonido de un violín y creerá que es su padre. Sin embargo, al alcanzar una ventana que da a una habitación se introduce por un megáfono, porque cree que su padre está dentro de él tocando su violín. Es otra representación de ese mundo moderno y urbano desconocido para Fievel y que padece con decepción. Una vez más, descubierto por una mujer, es arrojado sin piedad del piso. A fin de cuentas, no deja de ser un ratón. Cae en un cubo de agua sucia que es vaciado por otra mujer, arrastrando suciedad y desperdicios que, casualmente, le conducen a los pies de Toni, ese despierto ratón que le pone el nombre americanizado de Fili. Y decide ser su protector al conocer la debilidad de Fievel. Esta muestra de solidaridad, tras el rechazo y las amargas decepciones que ha vivido, representa ese aspecto psicológico crucial para quien ha perdido sus referentes anteriores, su familia o país. Además, esta ambientación exclusivamente urbana fue un rasgo típico del nuevo inmigrante, ya que se produjo un "amontonamiento de extranjeros" (Degler, 1986: 69) que contrastó con una dispersión de los americanos por el extenso territorio. Esto provocará el surgimiento de guetos por nacionalidades (el nombre de los barrios los caracteriza claramente, Little Italy o Chinatown) y, también, como era de esperar, de bolsas de pobreza (VV.AA, 1980: 479).

El filme, en este sentido, no descuida trazar, sutilmente, un cuadro realista y vivo de sus padecimientos. Pero esto no evita insistir sobre los valores americanos, cuando Toni, seguido por Fievel, se encuentra en un mercado con Briget. Toni, en ese apunte romántico amoroso, se ve hechizado por ella. Briget está subida en un alto a modo de oradora, dirigiéndose a un grupo de ratones: "Esto es América, no tengan miedo. ¿Vamos a dejar que los gatos nos 
pisoteen?". Les pide que se unan contra ellos porque es la única manera de hacerles frente. "Esto es América, hay libertad de expresión, se puede decir gato, gato...", lo que conmociona a los ratones que le escuchan y se alejan asustados. Fievel interviene afirmando que no hay gatos en América. Sin embargo, una sombra se cierne sobre él: los gatos entran en acción persiguiendo a los ratones.

En el filme, América se caracteriza por dos factores trascendentales: la libertad individual y la libertad de expresión, al menos, en sus rasgos distintivos. La escena en la que se muestra que hay gatos termina con la madre de Fievel reprochándole a su marido: "Qué cosa no hay en América", a lo que él no puede sino manifestar forzosamente: "Gatos". Toda tierra prometida tiene sus aspectos negativos y desafíos. La inmigración provocó reacciones contrarias en la sociedad americana. Y, por supuesto, se generaron muchas fobias, en especial, contra los católicos (al considerarlos como un poder extranjero dominado por Roma) o contra los mismos judíos. Porque el antisemitismo americano "había existido siempre y estaba arraigado en los orígenes europeos del país" (Adams, 1985: 190), si bien, con otros matices.

En cuanto a los judíos, brotaron los mismos prejuicios sobre su prosperidad que causaron malestar entre los americanos cuando se produjeron coyunturas económicas desfavorables. Reacciones adversas que se agravaron, además, por la llegada de miles de judíos de Europa del Este (como la familia de Fievel). De este modo, en el último tercio del siglo XIX, "la discriminación social y económica fue en aumento y el anti-semitismo se dejó sentir en las restricciones a la inmigración, orientadas veladamente contra el pueblo judío" (Hernández Alonso, 1996: 443). En otras palabras, la actitud en América no fue tan abierta y generosa. Si bien, no tenía tanto que ver con las persecuciones que sufrieron en Europa. Incluso hubo inmigrantes que retornaron al continente tras un periodo de tiempo viviendo allí. No quisieron adaptarse, ni aprender inglés. Su idea era trabajar, ganar un dinero y luego regresar a Europa (Adams, 1985: 190). No fue el caso de los judíos de origen ruso que se afincaron en América. En suma, no todos se vieron seducidos por el sueño americano.

Volviendo al filme, Fievel, acompañado por Toni y Briget, va a ver a Juan el honesto que conoce a todos los ratones para saber si tiene noticias de su familia. Juan encarna a los políticos oportunistas; es demagogo y bebedor. Se presenta vestido con elegancia, con una copa de cóctel en una mano y trazas de estar borracho. Se acerca a un ratón muerto al que apunta en un cuaderno afirmando que es una pena que no pueda votar, pero que él se encargará de que sea así. También se refiere a Honorio y los pagos que hace por su protección, revelando sutilmente la existencia de mafias. La aparición de "la ratona más rica" revela otros rasgos de ese paralelismo histórico cuando ella se asombra de ver un ratón muerto en una mesa. A lo que Juan le replica con humor negro que es "una tradición irlandesa". Y subraya la influencia que cobra la cultura irlandesa en América, debido a la crisis de la patata que empujó a muchos irlandeses a América para no morir de hambre (Degler, 1986: 64).

Por lo tanto, no sólo se destaca, una vez más, la multiculturalidad sino un cierto elitismo cuando la ratona rica se queja con amargura de que los gatos no distingan entre ricos y pobres. Por lo que le pide a Juan que los pobres, a los que ella dice ayudar, han de hacer algo por ella, reunirse en un frente para oponerse a los gatos. Lamentablemente, Juan le contesta que no conoce a la familia de Fievel.

Al margen de las diferencias sociales o culturales, los ratones, ricos y pobres, han decidido reunirse en un parque con el fin de decidir cómo afrontar el problema de los gatos. La ratona rica está en lo alto de una tribuna de oradores, secundada por un policía y por Juan 
el honesto. Algunos manifiestan su miedo a que le oigan, otra afirma: "Usted puede hablar porque es rica". A lo que replica que el dinero no lo es todo y exclama: "Pero, iqué valor tiene sin libertad!". Y un coro de voces lo confirma. Ella prosigue su discurso: "¿Para qué vinimos a América? Para ser libres". Y señala a la Estatua de la Libertad como símbolo de lo que dice. "¿Qué es lo que queremos?", a lo que le replican a coro: "iLibertad!". En suma, ella concluye que como "están en América" pueden lograrlo. Lo cual trae consigo un mar de aplausos. Pero cuando pide alguna idea para hacerlo posible sólo se escucha el silencio y el desaliento del público. Hasta que, de pronto, Fievel se acerca a la ratona rica. Oculto por el atril y al oído, le susurra su idea. Ella le cuenta a Juan lo que le ha dicho. Y, finalmente, la ratona grita que tienen un plan. Esta solidaridad entre ratones de diversas procedencias genera un cambio social. Ya no son ratones de diferentes estratos, ricos o pobres, judíos o católicos, sino que todos bogan por una misma causa común: acabar con su enemigo mortal, los gatos. Esto se traduce en la unión contra la intolerancia y la brutalidad. La solidaridad entre iguales, con el fin de alcanzar la libertad, se convierte en el motivo principal de su proclama.

El papel de las mujeres en América, además, cobra un mayor protagonismo en las figuras de Briget y la ratona rica, participan activamente en las decisiones y en la política, mientras que la madre de Fievel ostenta un papel secundario. Juan el honesto representará a unas "instituciones inmóviles, recalcitrantes, oportunistas y muchas veces corruptas" (Bosch, 2005:275), sobre las que el filme no se detendrá, pero que se podría calificar como una caracterización de la época. Ya que, por encima de la política y los políticos, late el corazón de la voluntad popular, el verdadero guardián de la libertad y representante de la sociedad americana. La película se olvida de retratar o mencionar a la sociedad nativa americana, y los recelos y reacciones negativas que trajo consigo la llegada de tantos millones de inmigrantes que ostentaban rasgos tan diferentes (VV.AA, 1980: 481). De tal modo que da la impresión de que esta transformación de los inmigrantes en americanos es, ante todo, espiritual, como si América fuera algo más que una tierra de provisión para erigirse como una idea en sí.

Esa noche, de nuevo en el filme, en el puerto, los ratones con velas encendidas entran en procesión a un edificio clausurado, el museo de los horrores. Armados con diferentes instrumentos, sierras, tijeras y demás, se ponen manos a la obra. Hilan, cosen, preparan pociones, trasladan una calavera, latas, etc... Mientras la comunidad prepara su invento, Toni y Fievel se han retrasado. Sin embargo, una vez más, Fievel se mete de lleno en otra aventura. Escucha el sonido de un violín, piensa que es su padre y se separa de Toni. Se introduce por una alcantarilla oscura y lóbrega hasta dar de bruces con un grupo de gatos. El que toca el violín es Honorio, un gato. Fievel lo descubre sin su disfraz, por lo que es atrapado y encerrado en una jaula. Por fin, aparte de Honorio, los gatos se personalizan. Adquieren unos rasgos definidos, no abstractos y vulgarmente negativos como en otras escenas. Destaca un gato rubio, Tigre. A partir de aquí no todos los gatos son iguales ni proverbialmente se les puede calificar de crueles. Tigre vigila a un asustado Fievel. Y éste le pide que se tranquilice: "No te haré nada" y le anima: "Vamos, por qué no te ríes". Fievel asoma su cabecita y con su voz infantil le responde que llora por estar encerrado y por querer encontrar a su familia. Lo que provoca en Tigre una reacción de solidaridad y afecto: "¡Qué terrible!". Porque también él perdió a su familia. Así que se pone a llorar. Los papeles se intercambian y Fievel, optimista, le dice que no se preocupe, que seguro que la encuentra. Tigre es un gato especial, le gustan los ratones, "pero no de la forma que crees", le espeta a Fievel, cuando éste se pone a llorar creyendo que se lo va a comer. "Es más", sentencia, "yo no como carne roja, nunca". 
Se declara vegetariano. Pero Fievel, en su elocuente sinceridad, le señala que él creía que todos los gatos eran "malos". Tigre es diferente y comprueban que tienen gustos similares (las mariposas, el helado de queso, etc.).

Aunque es imposible negar las grandes diferencias entre ratones y gatos, eso no es indicativo, según el filme, de que no puedan convivir en paz y armonía. Por lo tanto, se idealiza un panorama que no fue tan fácil para los inmigrantes, que tuvieron que adaptarse a este acrisolado marco que venía definido por las clases dominantes americanas que habían construido el país un siglo antes (Adams, 1985: 192).

La huída de Fievel, gracias a la ayuda de Tigre, determina la siguiente escena, ya que se encamina al museo de los horrores donde se han reunido todos los ratones. Duermen porque aún no es la hora. Pero el grito de Fievel de que vienen gatos induce a movilizarlos, dando pie a lanzar "el arma secreta" que han preparado. Honorio, otra vez disfrazado de ratón, les pide que le entreguen el dinero y a Fievel (que sabe su secreto), a cambio de ordenar a los gatos que les dejen en paz. Fievel pide que no le crean porque es un gato y Toni, con habilidad, lanza con su tirachinas a Honorio varias piedras que le hacen perder su falsa caracterización como roedor.

Descubierta, de esta forma, la faz ruin de Honorio, aún prepara su última jugada y enciende una cerilla prendiendo una caja de algodón con el fin de acabar con los ratones. La ratona rica da la señal para que suelten el arma... Otros tocan con una trompetita la carga del $7^{\circ}$ de Caballería (un elemento muy americano). El arma no se suelta y Fievel rápidamente, con una antorcha, quema la cuerda que la sujeta. Con estruendo sale "el ratón gigante de Minsk". Los gatos, al ver a ese falso ratón gigante que se les echa encima a toda velocidad, salen despavoridos en dirección al muelle. Y caen al agua. Todos se ponen a cantar: "Porque no hay gatos en América...".

Los gatos se han subido al ancla del barco Star of Hong Kong. Sin duda, su destino les arrastrará lejos, desterrados para siempre. El peligro no ha pasado. Fievel, tras su heroico acto, se ha quedado inconsciente. Una lata de queroseno prende y todo arde. Toni y Briget han encontrado la gorra de Fievel y se ponen a buscarlo. El agua de las mangueras de los bomberos que sofocan el incencio arrastra a Fievel a un paraje desconocido. Le recogen tres ratones. Se ríen de Fievel cuando les dice que busca a su familia: "Al menos tú sabes quiénes son", lo que indica que son de una clase social marginal. Con frialdad le indican que ellos deberían buscarle a él: "No te quieren, olvídalos". Eso provoca la reacción pesarosa de Fievel, asumiendo que, tal vez, tengan razón. Y desconsolado afirma: "De todas formas, nunca los encontraré, nunca, nunca". Llueve y truena y varias docenas de ratones se hallan a cubierto, durmiendo recogidos. Esta escena casi final incide una vez más en las penurias de los miles de inmigrantes. Lo cual coincide con las malas condiciones laborales que soportaron: "el hacinamiento era proverbial y la higiene no pertenecía a ese mundo" (Hernández Alonso, 1996: 454). Hay un velo dramático, pese a tratarse de un filme de dibujos animados, y crítico tras la imagen que radiografía, aún con su historia infantil, la dura estampa de la vida del inmigrante en las ciudades americanas. Sin embargo, lo que prevalece es la solidaridad y la familia. Así, su familia, junto a la dama rica, Toni y Briget, subidos a lomos de Tigre, conducen la búsqueda de Fievel. El padre toca la música distintiva de su violín. Y Fievel, despierto, escucha su familiar sonido. El padre oye la dulce voz de su hijo perdido llevándoles al emotivo reencuentro. En ese instante, Tigre expresa que tiene cientos de pequeños amiguitos. Pero en ese punto y final tan singular la madre, que tiene a Fievel en su regazo, afirma simbólicamente: "Amé- 
rica, iqué lugar!". El padre le devuelve a Fievel la gorra que ya no le está tan grande: "Eres un auténtico ratón". No obstante, es muy simbólica la última escena. Henry, el palomo, lleva en su lomo tanto a Fievel como a su hermana, Tania, para enseñarles algo magnífico. Otra paloma porta a sus padres, y otras a Tigre al que cogen por las patas, porque es más pesado. Por supuesto se dirigen hacia la Estatua de la Libertad. "¡Oh, Henry, es tan bella!", señala la hermana de Fievel. En ese instante, la Estatua guiña un ojo a los dos hermanos que se miran sorprendidos e iluminados.

Fievel: Oye, Henry, ¿qué es aquello?

Henry: Todo aquello también es América.

Fievel: ¿Podíamos ir a ver?

Henry: ¡Oh! jojojo. Lo harás mi pequeño americano, algún día lo harás...

Los dos hermanos se despiden de la Estatua, última imagen del filme, dejando un final abierto hacia las demás entregas de la saga. Y tal como indica Juan José Hernández, al final, "los judíos fueron cambiando una ortodoxia a unas creencias conservadoras y reformistas llegando incluso algunos a una pérdida de identidad religiosa, sustituida por ideas políticas de progreso" (1996: 456). Algo que está presente en el filme porque se les tilda de americanos. Lo que, realmente, han adquirido son los ideales americanos que vienen a estar representados por su lucha por la libertad contra los gatos y por un hermanamiento intercultural e interclasista. Si bien, aunque pudieran existir, no cabe la menor duda de que, en mayor medida, este tipo de relaciones venían marcadas por el grupo de pertenencia étnico, más que por los ideales americanos adquiridos (Adams, 1985: 200). Es, por ello, una visión sumamente positiva que contrasta con una realidad más cruda y adversa como hemos podido valorar, un happy end que clarifica el mensaje final del filme y que coincide con la interpretación optimista y positiva, a mi entender, que hace Johnson de la capacidad tanto de Norteamérica como, en concreto, de Nueva York de "transformar a millones de inmigrantes, muchos de los cuales llegaban al país sin dinero y con temor, en ciudadanos seguros de sí mismos, generadores de riqueza y seres social y culturalmente útiles" (Johnson, 2001: 536). No fue ni tan perfecto ni tan sencillo, con tensiones, violencia y unas profundas simas sociales (Adams, 1985: 196).

\section{A MODO DE CONCLUSIÓN}

El historiador Rosenstone indica que "aceptar la invención es, por supuesto, cambiar significativamente nuestra manera de entender la historia" (1997: 63). No hay duda de que los dibujos animados se presentan como una invención en sí misma, si bien, hemos podido valorar cómo realiza el tratamiento histórico de lo que fue la suerte de millones de inmigrantes en Estados Unidos. Fievel y el nuevo mundo se caracteriza por no ser un producto típicamente infantil, como cabría pensarse, y ahí radica su relevancia dentro de este análisis. Caracteriza no sólo un siglo XIX enturbiado por una inmigración producto de la necesidad sino de la persecución, como es el caso de los judíos encarnados en la familia de Fievel, lo que lo convierte en un homenaje al papel que ha jugado Estados Unidos en sus vidas como lugar de acogida.

En ese contraanálisis de la sociedad se comprueba como el filme retrata aspectos ásperos en la recepción de esta población. Si bien, la libertad, tal y como señala el filme, no es un elemento de cohesión social tan fuerte como se presenta en el imaginario norteamericano. 
Tal vez lo sería después, pero no en ese contexto histórico en el que se ambienta. A pesar de que América (identificada como Estados Unidos) es esa tierra de promesas y existe la necesidad de que el final de la historia tenga un balance feliz y positivo, a tenor de que una parte del público al que está dirigido es infantil, se observa una cierta composición trágica. La visión de los gatos es terrorífica, así como cuando Fievel es recogido por Honorio y vendido como mano de obra barata, o la situación de desamparo de los ratones cuando duermen a la intemperie. Pero sobre esta crudeza se construye la esperanza simbolizada, claramente, en la Estatua de la Libertad y en las motivaciones que contiene en los protagonistas el espíritu americano del que se ven contagiados. Fievel no esconde una radiografía tersa de la vida, como es la separación familiar durante el viaje y motivo de las desventuras de Fievel, que anhela reunirse con ellos. Con todo, el mito de la libertad está muy presente y se consagra en la Estatua de la Libertad. En suma, en América triunfa no sólo la libertad sino la diferencia de razas y culturas, que en su fusión trascendente acaban por crear al auténtico americano. Y los dibujos animados se utilizan para amueblar una ideología dominante. Pero que, a la vez, encarna los considerados rasgos característicos de la civilización estadounidense, que "no ha sido homogénea ni uniforme, sino que está definida por la diversidad y el pluralismo" (Degler, 1986: p. 76).

\section{BIBLIOGRAFÍA}

ADAMS, W. P. (1985), Los Estados Unidos de América, Madrid, Siglo XXI.

BLANCO, C. (2000), Las migraciones contemporáneas, Madrid, Alianza.

BOSCH, A. (2005), Historia de Estados Unidos, Barcelona, Crítica.

DEGLER, C. N. (1986), Historia de Estados Unidos, Barcelona, Ariel.

DE PABLO, S. (2001): "Cine e Historia: ¿La Gran Ilusión o La amenaza fantasma?", Historia Contemporánea, núm. 22, pp. 9-28.

FERRO, M. (1995), Historia contemporánea y cine, Barcelona, Ariel.

HERNÁNDEZ ALONSO, J. J. (1996), Los Estados Unidos de América: Historia y cultura, Salamanca, Colegio de España.

JOHNSON, P. (2001), Estados Unidos, Barcelona, Edificios B.

NASH, M. (2003), "Representaciones culturales y discurso de género, raza y clase en la construcción de la sociedad europea contemporánea", NASH, Mary y MARRE, Diana (eds.), El desafío de la diferencia, Bilbao, UPV.

NOVICK, P. (2007), Judíos, ¿vergüenza o victimismo?, Madrid, Marcial Pons.

ROSENSTONE, R. A. (1997), El pasado en imágenes, Barcelona, Ariel.

SUÁREZ, L. (2003), Los judíos, Barcelona, Ariel.

V.AA. (1980), Breve historia de los Estados Unidos, México, FCE.

Quaderns, 6 (2011), pp. 7-18 